\title{
Epitope Analysis of Staphylococcal Enterotoxin A Using Different Synthetic Peptides
}

\author{
Dong-Liang HU, Ayako IMAI, Katsuhiko ONO, Sanae SASAKI ${ }^{1)}$, Akio NAKANE ${ }^{1)}$, Shunji SUGII ${ }^{2)}$ and \\ Kunihiro SHINAGAWA* \\ Department of Veterinary Medicine, Faculty of Agriculture, Iwate University, 3-18-8 Ueda, Morioka, Iwate 020-0066, ${ }^{1}$ Department of \\ Bacteriology, Hirosaki University School of Medicine, Zaifu-cho, Hirosaki 036-8216, and 2)Department of Veterinary Science, College \\ of Agriculture, Osaka Prefectural University, Gakuen-cho, Sakai, Osaka 599-8531, Japan
}

(Received 27 February 1998/Accepted 1 May 1998)

ABSTRACT. The antigenic determinants (or epitopes) of staphylococcal enterotoxin A (SEA) were analyzed using synthetic peptides and rabbit antibodies to their corresponding peptides. Of 12 different synthetic peptides tested, peptides A-1 (corresponding to the amino acid sequence 1-20), A-5 (81-100), and A-8 (141-160) were reactive with anti-SEA antibodies. However, all synthetic peptides were found to elicit antibodies reactive with native SEA molecule. These findings suggest that native SEA molecule contains at least 3 different antigenic determinants. - KEY wORDs: enterotoxin, epitope, peptide, Staphylococcus aureus.

J. Vet. Med.Sci. 60(9): 993-996, 1998

The staphylococcal enterotoxins (SEs) induce emesis and diarrhea in humans and other primates $[2,3]$. They are serologically classified into six types: A (SEA), B (SEB), C $\left(\mathrm{SEC}_{1}, \mathrm{SEC}_{2}\right.$, and $\left.\mathrm{SEC}_{3}\right), \mathrm{D}(\mathrm{SED}), \mathrm{E}(\mathrm{SEE})$, and $\mathrm{H}(\mathrm{SEH})$ $[1,4-8,12,16]$. Although SEs are serologically distinct, cross-reacting antibodies in polyclonal sera to purified SEs have been observed [14, 15]. Specific and cross-reacting epitopes on SEs have been studied using tryptic fragments and different monoclonal antibodies $[10,11]$. However, the biologically and functionally active sites of SEs have not yet fully been understood by these studies. Thus, attempts were made to investigate the antigenic determinants (or epitopes) of SEA which are supposed to be associated with the active site(s) by use of different synthetic peptides and their antibodies.

\section{MATERIALS AND METHODS}

SEA and rabbit antiserum against SEA: SEA was prepared from $S$. aureus strain FRI-722 by the methods described previously [14]. Rabbit antiserum against SEA was prepared by the methods described previously [15].

Synthetic peptides: Reagents for peptide synthesis were obtained from Shimadzu Co., Ltd., Kyoto, Japan. According to the nucleotide and/or deduced amino acid sequences of SEA reported previously [9, 13], peptides corresponding to the entire sequences of SEA were synthesized with a Shimadzu PSSM-8 automated peptide synthesizer (Shimadzu Co., Ltd., Kyoto, Japan) using N-(9-fluorenyl) methoxycarbonyl chemistry. The peptides were 20 -mers representing the following amino acid residues of the SEA with 27,078 daltons: 1 to 20 (A-1), 21-40 (A-2), 41-60 (A3), 61-80 (A-4), 81-100 (A-5), 101-120 (A-6), 121-140

* Correspondence to: Shinagawa, K., Department of Veterinary Medicine, Faculty of Agriculture, Iwate University, 3-18-8 Ueda, Morioka, Iwate 020-0066, Japan.
(A-7), 141-160 (A-8), 161-180 (A-9), 181-200 (A-10), 201-220 (A-11), 221-233 (A-12) and 101-118 (A-homo). The amino acid alignment of synthetic peptides is shown in Table 1. The peptides were cleaved from resins with trifluroacetic acid/anisole/ethandithiol, trifluroacetic acid/ anisole/ethandithiol/methylindole, trifluroacetic acid/ thioanisole/ethandithiol/dimethyl sulfate, or trifluroacetic acid/thioanisole/ethandithiol/dimethyl sulfide/phenol/ methylindole at different ratios according to the instruction of the manufacturer. The cleaved peptides were then extracted in ether and subsequently dissolved in distilled water and lyophilized [17].

Preparation of rabbit antisera to synthetic peptides: Rabbit antisera to synthesized peptides were produced by hyperimmunization of albino female rabbits. For immunization, $1 \mathrm{mg}$ of each peptide in distilled water was conjugated to $1 \mathrm{mg}$ of ovalbumin (Sigma Chemical Co., St. Louis, MO, U.S.A.) in distilled water using $3 \mathrm{mg}$ of 1-

Table 1. Structures of synthetic peptide fragments of SEA

\begin{tabular}{lcl}
\hline No. & Position $^{\text {a) }}$ & Amino acid sequence \\
\hline A-1 & $1-20$ & SEKSEEINEKDLRKKSELQG \\
A-2 & $21-40$ & TALGNLKQIYYYNEKAKTEN \\
A-3 & $41-60$ & KESHDQFLQHRILFKGFFTD \\
A-4 & $61-80$ & HSWYNDLLVDFDSKDIVDKY \\
A-5 & $81-100$ & KGKKVDLYGAYYGUQCAGGT \\
A-6 & $101-120$ & PNKTACMYGGVTLHDNNRLT \\
A-7 & $121-140$ & EEKKVPINLWLDGKQNTVPL \\
A-8 & $141-160$ & ETVKTJKKNVTVQELDLQAR \\
A-9 & $161-180$ & RYLQEKYNLYNSDVFDGKVQ \\
A-10 & $181-200$ & RGLIVFHTSTEPSVNYDLFG \\
A-11 & $201-220$ & AQGQYSNTLLRIYRDNKSIN \\
A-12 & $221-233$ & SENMHIDIYLYTS \\
A-homo & $101-118$ & PNKTACMYGGVTLHDNNR \\
\hline
\end{tabular}

a) Residue number corresponding to SEA starting at the amino-terminal end (N-terminal) of the molecule.

b) A-homo: Amino acid sequence homology in enterotoxins. 
ethyl-3-(3-dimethylaminopropyl)-carbodiimide (Sigma Chemical Co., St. Louis, MO, U.S.A.) by allowing the mixture to stand at room temperature for $2 \mathrm{hr}$. After coupling, the mixture was extensively dialyzed against PBS. After dialysis, the complex was mixed with Freund's complete adjuvant to make an emulsion. The emulsion containing 300-500 $\mu \mathrm{g}$ of the synthetic peptide was injected subcutaneously into a rabbit/each peptide once a week for three weeks. After antibody production was confirmed by gel double immunodiffusion, rabbit sera were obtained. The $\mathrm{IgG}$ fraction was isolated by affinity chromatography on Affi-Gel Protein-A (Bio-Rad, Laboratories, U.S.A.). Rabbit anti-SEA antibody (IgG) was also isolated in the same manner.

Enzyme-linked immunosorbent assay (ELISA): Enzymelinked immunosorbent assay was carried out in triplicate with microtiter plate as reported previously [17]. For color development, the substrate solution containing $0.02 \% \mathrm{H}_{2} \mathrm{O}_{2}$ and $1 \mathrm{mg} / \mathrm{ml}$ of $o$-phenylenediamine in $0.1 \mathrm{M}$ citratephosphate buffer ( $\mathrm{pH}$ 5.0) was added to each well. To stop the reaction, $50 \mu l$ of $5 \mathrm{~N} \mathrm{H}_{2} \mathrm{SO}_{4}$ was added to each well. The enzyme-substrate reaction was determined spectrophotometrically with Titertek Multiscan MC type 346-2 (Flow Laboratories) at $492 \mathrm{~nm}$.

\section{RESULTS AND DISCUSSION}

The reactivity of anti-SEA antibody with synthetic peptides: To identify which synthetic peptides are most antigenic to rabbit antibodies to native SEA molecule, the peptides were tested for their abilities to bind the antibodies. With the synthetic peptides at $20 \mu \mathrm{g} / \mathrm{m} l$ used for coating, peptides A-1 (corresponding to the amino acid sequence 1-
20) and A-8 (141-160) were found to show the higher binding activity to the antibodies, whereas other peptides were found to weakly react with the antibodies (Fig. 1). With peptides at $400 \mu \mathrm{g} / \mathrm{m} l$ used for coating, however, peptides A-5 (81-100) and A-8 (141-160) were higher reactive with the antibodies than the others (Fig. 2). These findings suggest that native SEA molecule contains at least three different antigenic determinants within a single polypeptide.

The reactivity of anti-synthetic peptide antibodies with native SEA: Since at least three different antigenic determinants are shown to be located on native SEA molecule, rabbit antibodies against synthetic peptides were prepared. They were tested for their reactivities with native SEA molecule to determine which anti-peptide antibodies are most reactive with native SEA. These synthetic peptides were found to elicit rabbit antibodies reactive with their respective peptides. As shown in Fig. 3, the highest reactivity of native SEA molecule was obtained with rabbit antibody to peptide A-5 (81-100). The higher reactivities were obtained with antibodies to A-8 (141-160), A-7 (121$140)$ and A-2 (21-40). Other rabbit antibodies to other synthetic peptides were also reactive with native SEA molecule. But antibody to A-12 (221-233) showed weekly reactivity with native SEA (Fig. 3). These findings suggest that the regions of native SEA molecule corresponding to all synthetic peptides used may be exposed to the surface or that all anti-peptide antibodies may be properly accessible to the corresponding antigenic determinants of native SEA.

From the present findings, these synthetic peptides prepared were found to be immunogenic. These suggest that these peptides and their antibodies will be useful tools to analyze specific and/or cross-reacting epitopes on SEs.

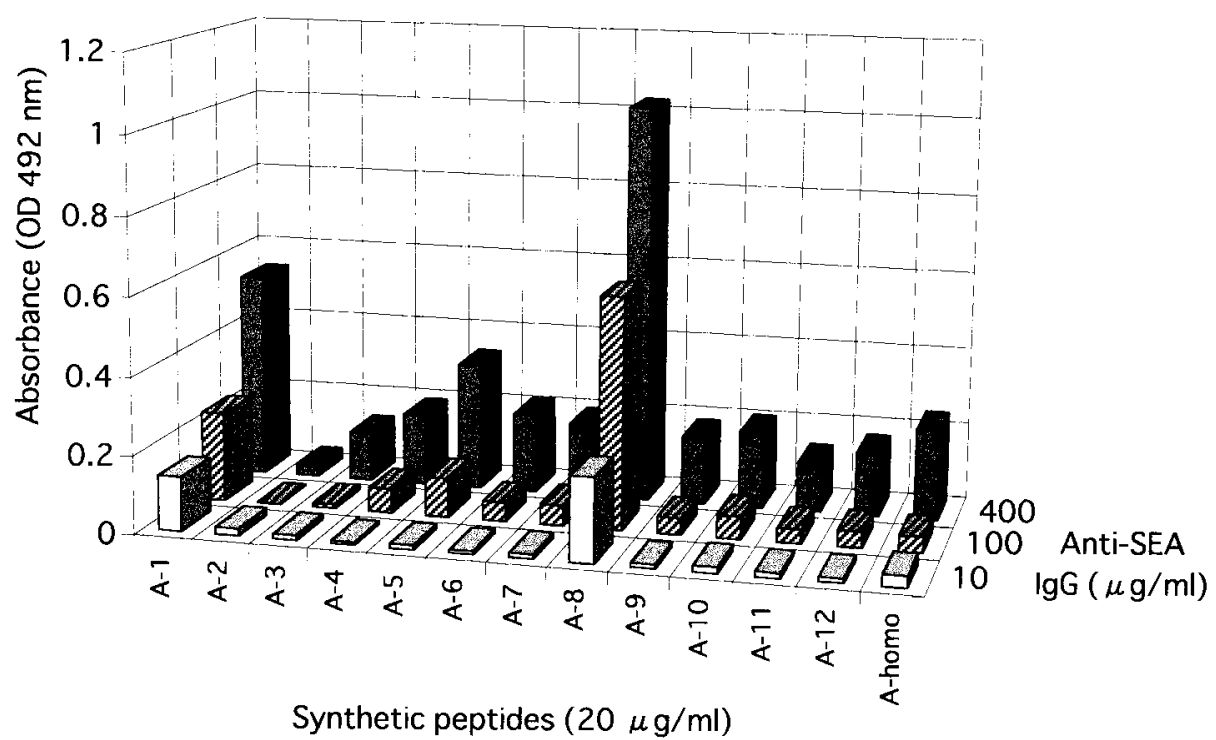

Fig. 1. Binding assays with rabbit anti-SEA IgG and synthetic peptides as determined by ELISA. Synthetic peptides were used at the concentration of $20 \mu \mathrm{g} / \mathrm{m} l$. Anti-SEA IgG were used at the concentration of 10,100 and $400 \mu \mathrm{g} / \mathrm{m} l$ respectively. Each result represents the mean value for three test wells. 


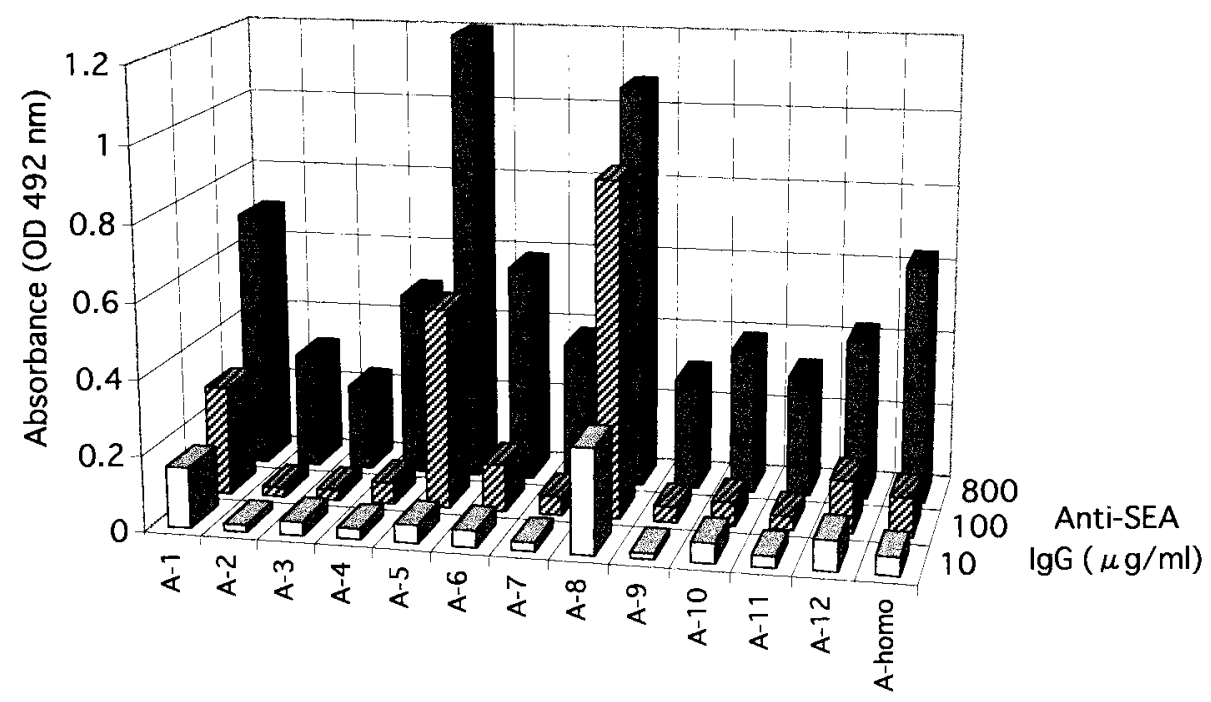

Synthetic peptides $(400 \mu \mathrm{g} / \mathrm{ml})$

Fig. 2. Binding assays with rabbit anti-SEA IgG and synthetic peptides as determined by ELISA. Synthetic peptides were used at the concentration of $400 \mu \mathrm{g} / \mathrm{m} \mathrm{l}$. Anti-SEA IgG were used at the concentration of 10,100 and $800 \mu \mathrm{g} / \mathrm{m} l$ respectively. Each result represents the mean value for three test wells.

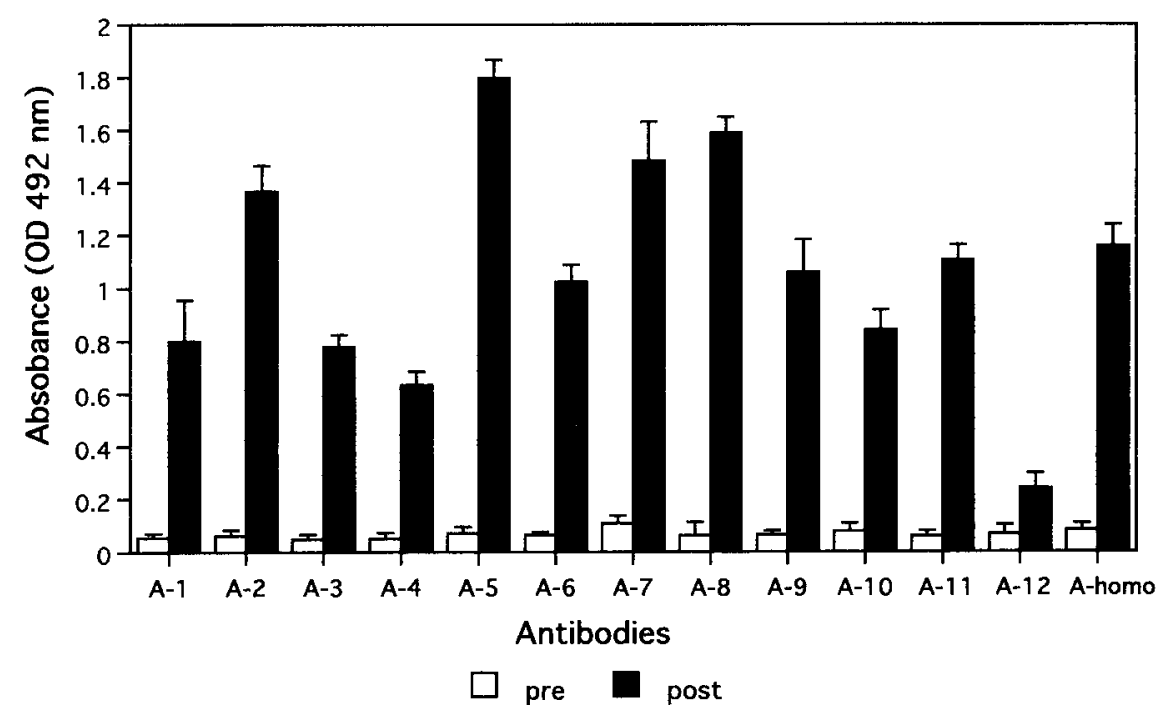

Fig. 3. Reactivity of rabbit anti-synthetic peptide antibodies with SEA as determined by ELISA. Antibodies ( $\mathrm{IgG}$ ) were used at the concentration of $100 \mu \mathrm{g} / \mathrm{m} l$. Representative data from one of three experiments are presented as mean absorbance \pm SD. Absorbance with IgG from Preimmune (open bars) and immunized (solid bars) sera were shown.

Further detailed studies on biologically and functionally active sites on SEA will be carried out by synthetic peptides of different sizes newly prepared in future.

ACKNOWLEDGMENT. This study was supported in part by a Grant-in-Aid for Scientific Research from the Ministry of Education, Science, and Culture of Japan.

\section{REFERENCES}

1. Avena, R.M. and Bergdoll, M.S. 1967. Purification and some physicochemical properties of enterotoxin C, Staphylococcus aureus strain 361. Biochemistry 6: 1474-1480.

2. Bergdoll, M.S. 1977. Immunological aspects of staphylococcal enterotoxins. pp. 199-220. In: Immunological Aspects of Foods (Catsmpoolas, N. ed.), The AVI Publishing Co., Inc., 
Westport, Conn.

3. Bergdoll, M.S. 1979. Staphylococcal intoxications. pp. 443494. In: Food-Borne Infections and Intoxications, 2nd ed. (Riemann, H. and Bryan, F. L. eds.), Academic Press Inc., New York.

4. Bergdoll, M.S., Surgalla, M.J. and Dack, G.M. 1959. Staphylococcal enterotoxin: identification of a specific precipitating antibody with enterotoxin neutralizing property. J. Immunol. 83: 334-338.

5. Bergdoll, M.S., Borja, C.R. and Avena, R.M. 1965. Identification of a new enterotoxin as enterotoxin C. J. Bacteriology 90: 1481-1485.

6. Bergdoll, M.S., Borja, C.R. Robbins, R.N. and Weiss, K.F. 1971. Identification of enterotoxin E. Infect. Immun. 4: 593595.

7. Casman, E.P. 1960. Further serological studies of staphylococcal enterotoxin. J Bacteriol. 79: 849-856.

8. Casman, E.P., Bennett, R.W. Dorsey, A.E. and Issa, J.A. 1967. Identification of a fourth staphylococcal enterotoxin, enterotoxin D. J. Bacteriol. 94: 1875-1882.

9. Huang, I-Y., Hughes, J.L., Bergdoll, M.S. and Schantz, E.J. 1987. Complete amino acid sequence of staphylococcal enterotoxin A. J. Biol. Chem. 262: 7006-7013.

10. Lee, A.C., Robbins, R.N., Reser, R.F. and Borgdoll, M.S. 1980a. Isolation of specific and common antibodies to staphylococcal enterotoxin A and E by affinity chromatography. Infect. Immun. 21: 387-391.
11. Lee, A.C., Robbins, R.N., Reser, R.F. and Borgdoll, M.S. 1980b. Isolation of specific and common antibodies to staphylococcal enterotoxin $\mathrm{B}, \mathrm{C} 1$ and $\mathrm{C} 2$. Infect. Immun. 27: 431-434.

12. Reiser, R.F., Robbins, R.N., Noleto, A.L., Khoe, G.P. and Bergdoll, M.S. 1984. Identification, purification, and some physicochemical properties of staphylococcal enterotoxin $\mathrm{C}_{3}$. Infect. Immun. 45: 625-630.

13. Schad, E.M., Zaitseva, I., Zaitsev, V.N., Dohlsten, M., Kalland, T., Schlievert, P.M., Ohlendorf, D.H. and Svensson, L.A. 1995. Crystal structure of the superantigen staphylococcal enterotoxin type A. EMBO.J. 14: 3292-3301.

14. Shinagawa, K., Nishimura, E., Mithumori, M., Matsusaka, N. and Sugii, S. 1991. Production and characterization of murine monoclonal antibodies against staphylococcal enterotoxins A and E. Can. J. Microbiol. 37: 581-585.

15. Shinagawa, K., Tachihara, R., Mithumori, M., Matsusaka, N. and Sugii, S. 1991. Immunological cross-reactivity of the fragments of staphylococcal enterotoxion $\mathrm{A}$ and $\mathrm{E}$ generated by digestion of proteolytic enzymes. J. Vet. Med. Sci. 53: 223-227.

16. Su, Y-C. and Wong, C.L. 1995.Identification and purification of a new staphylococcal enterotoxin, H. Appl.Environ. Microbiol. 61: 1438-1443.

17. Sugii, S. 1994. Analysis of multiple antigenic determinants of the bovine conglutinin molecule using different synthetic peptides. J. Vet. Med. Sci. 56: 1035-1041. 